\title{
The experience of oppression and the price of nonconformity: a brief biography of Adam Podgórecki
}

\author{
Daniel Wicenty ${ }^{1}$
}

Published online: 29 January 2018

(C) The Author(s) 2018. This article is an open access publication

\begin{abstract}
Adam Podgórecki (1925-1998), a sociologist, author of brilliant Chinesestyled parables and a compulsory immigrant, is merely acknowledged in certain circles of sociologists in the world. The present article offers, first, a sketch of Podgórecki's biography. As his life divided into two separate parts after he left communist Poland in 1977, he uniquely experienced dissimilar academic milieus, oppressive in Poland, then competitive abroad. What is emphasized both generated some problems for him as an old-fashioned "disobedient in thinking" thinker. Secondly, the text offers a brief analysis of selected papers of Adam Podgórecki and outlines the factors influencing the reception of his work in Western sociology. An explanation of his career path is grounded in some concepts of the sociology of knowledge.
\end{abstract}

Keywords Adam Podgórecki · Sociologists in communist Poland · Sociology of law Sociology of knowledge

In some circles of the world sociology, Adam Podgórecki (1925-1998) is contemporarily recognised as a co-author of the modern concept of the sociology of law. In this context, he is usually mentioned along with William M. Evan, with whom he founded in 1962 the Research Committee on Sociology of Law of the International Sociological Association. Among Polish sociologists, Podgórecki is above all associated with the development of two new disciplines: sociology of law and sociotechnics. He was the founder in 1961 of the Sociology of Law Division of The Polish Sociological Association and, in the same year, organized in Warsaw the first international conference on this subject. His groundbreaking book outlining

Daniel Wicenty

daniel.wicenty@ipn.gov.pl

1 University of Gdańsk, Institute of National Remembrance (IPN), Al. Grunwaldzka 216, 80-266 Gdańsk, Poland 
sociology of law as a new discipline was published in 1962 in Poland (see Podgórecki 1962), and was followed by a number of books, both in Polish and English (also translated to other languages), in which he elaborated theoretical and empirical foundations of this new branch of sociology.

Inspired by ideas of Aristotle and Petrażycki, Podgórecki undertook a systematic inquiry into the duality of sciences (and social sciences in particular) expressed in a parallel development of their theoretical and practical versions. His early elaboration of this conception was presented in a book published in 1962 in Poland, which was followed in 1966 by a book outlining foundations for a new practical discipline_-sociotechnics (see Podgórecki 1962, 1966). In the same year, Podgórecki founded a Division for Sociotechnics at the Polish Sociological Association and in 1972 the Research Committee on Sociotechnics at the International Sociological Association. He edited a series of volumes based on Polish conferences on sociotechnics and published other books on this topic in Poland and abroad. The two pioneering divisions of the Polish Association and their international counterparts became very active, organizing annual conferences and stimulating innovative research and publications.

In 2004, the Board of the Research Committee on Sociology of Law established the annual Adam Podgórecki Prize. The initiators of the Prize emphasised not only his remarkable intellectual merits, but also his personal attributes such as "his inimitable personal style, which was direct, engaging and uncompromising". "These statements should not be mistaken for ritual formulas used commonly on such occasions. This becomes abundantly clear when one becomes acquainted with Podgórecki's path of life, abounding in paradoxes and dramatic turning points. This article offers only a brief sketch of selected aspects of Adam Podgórecki's biography ${ }^{2}$ and the factors influencing the reception of his work in Western sociology.

\section{The time of the war and the post-war period}

Adam Podgórecki was born in Cracow in 1925 into the family of a Polish army officer. His father Franciszek was a charming and vivacious man. In addition to his career in the Army, he was involved in some business ventures and was a coorganiser of the 1st Slavic Philatelic Exhibition in Katowice in 1934. Podgórecki's mother Olga, of Russian descent, was a very cultured woman, known for her elegance and sense of humour. His sister, a few years younger, also Olga, studied chemistry in the 1950s, graduating with the academic degree of Engineer and then Master of Science. Just before the outbreak of the World War II, his father, a reserve officer, was called up for military service; in September 1939 he fought in Lviv and

\footnotetext{
${ }^{1}$ Quoted from: Research Committee on Sociology of Law, Adam Podgórecki Prize, http://www.isasociology.org/en/research-networks/research-committees/rc12-sociology-of-law/rc12-awards/, the last visit 10th May 2017.

${ }^{2}$ For some interesting biographical contents see also the IPSiR page (in Polish): http://www.ipsir.uw.edu. pl/o-instytucie/katedry-i-zaklady/katedra-socjologii-norm-dewiacji-i-kontroli-spolecznej/strony-pamieciprofesora-adama-podgoreckiego, the last visit 23rd November 2017.
} 
then with the Polish army he reached Hungary, where he remained till the end of the war.

What were Podgórecki's youthful fascinations? Did any specific books absorb him? Before the war, he lived with his family in Katowice in the Silesia district of Poland, where he attended school. We know that as a teenager he learned German to read German philosophers. He was 13 years old when the war broke out. When Silesia was annexed by the Germans, he escaped together with his mother and sister and spent the rest of the war on the estate of Count and Countess Poniński, his parents' friends. They were lodged in a village Charzowice (near Cracow) that was part of the Poniński estate. During the German occupation, Adam completed 2 years of junior high school and 2 years of senior (or secondary) school through the underground educational network. At that time, he also attended a private course in Kazimierza Wielka, a neighbouring small town, where, soon after the war ended, he passed examinations for the secondary education certificate, the so-called big matura. Attending underground classes, strictly forbidden by the German occupiers, exposed him to considerable risks. Even greater risks were associated with belonging to the Polish underground Home Army. Andrzej Kojder, one of Podgórecki's students, relates that his teacher, secretly contacted the Home Army in Charzowice and was sworn as a member. His job was to distribute underground press (Kojder 1999). Riding his bike to his classes and throughout his distribution area, he experienced air bombardments and many dangerous encounters with Germans. Yet he also discovered amazing home libraries in several manor houses in the neighbourhood and devoured countless volumes of classical European literature, philosophy, history, and various other disciplines.

Immediately after the war, Podgórecki returned to Katowice to secure a safe return for his mother and sister and helped them to resettle there. In 1945, he started law studies at the Jagiellonian University in Cracow. Upon graduating in 1949, he immediately proceeded to write a doctoral dissertation while simultaneously enrolled in sociological studies. In 1951, he defended his $\mathrm{PhD}$ thesis ("Trade Unions in the Development of 19th Century English Society") and also earned a Master's degree in sociology ("Sociology of a Scientific Institution").

The time of his studies at the Jagiellonian University influenced Podgórecki's intellectual formation in two noteworthy ways. Firstly, his doctoral advisor, Jerzy Lande, a pre-war professor of law and philosophy at the Vilnius and Jagiellonian Universities, was a disciple of an unrecognized pioneer of the sociology of law, Leon Petrażycki (1867-1931). The contact with the refined pre-war culture of the academic world and the first-class erudition was a value in itself, all the more so that by the late 1940s the ravages of Stalinism were clearly visible in Polish humanities. Pre-war professors, if they had not declared their allegiance to Marxism, were marginalized or dismissed and, consequently, prevented to have contacts with students. Lande was under enormous pressure, but he was courageous enough to tell a selected circle of students about Petrażycki's ideas, which were by then discredited as incompatible with the Marxist ideology (Podgórecki 1997: 59-61). Petrażycki and his ideas, espoused by Lande, captivated Podgórecki-a fascination that lasted effectively for the rest of his life (Podgórecki 1980/1981). It is also worthy of note that Lande was a close friend of a prominent Polish philosopher, 
Tadeusz Kotarbiński, another scholar who played an important role in Podgórecki’s life.

Secondly, in the late 1940s, Podgórecki became a member of the Club of the Logophagoi, a unique, unofficial organization, so far not widely known. ${ }^{3}$ The club, located in the YMCA in Cracow, existed from 1947 to 1949. Its activities were patterned on Western debating societies. Before every meeting, the club printed elegant personal invitations, which in the bleak post-war times must have been a major challenge. Logophagoi created a real enclave of a free intellectual discussion in the growing climate of Stalinist oppression. The range of discussed topics included aesthetics, political systems, class conflicts in the Bible, Oswald Spengler's The Decline of the West, the works of Arnold Toynbee and Hermann Graf Keyserling. Its members remember the club as a superb school of confrontation, argumentation, and fact analysis. Not just the topics but also the group of invited guests and speakers was quite remarkable in its diversity and quality. The group included poets, writers, philosophers, artists, journalists, and priests. Among the club visitors were Zbigniew Herbert (one of the best Polish poets, who studied law at the Jagiellonian University more or less at the same time as Podgórecki did), the writers Paweł Jasienica and Stefan Kisielewski, pre-war philosophy professors Władysław Tatarkiewicz and Roman Ingarden, as well as scientists and even some Marxists. Podgórecki breathed in the air of refinement, tradition, discussion and, in a way, snobbery, all certainly intoxicating for a young mind. While he was not one of the close circle of organisers of the club's life, he attended its meetings and became involved in a Club-related informal quasi-publishing activity. He searched for the works of those scholars and literary people who had no real chances of having their works published under the rising communist censorship. In this way works by Jan Józef Szczepański, Leopold Tyrmand, and Władysław Tatarkiewicz were secured and informally published. Logophagoi had their roots in liberal, gentry, Catholic, and patriotic traditions. Quite a few had been in the Home Army. They tried to find their place in the new, post-war reality of the "growing Stalinization and sovietization of Poland"-as remembered by one of the Logophagoi, Andrzej Wielowieyski (Rozmarynowicz 1996: 68). The unmistakable signs of Stalinist terror were becoming evident everywhere. In the case of sociology, university faculties were being closed, syllabuses were altered, and eventually the recruitment of new students was stopped. Young communist activists started to appear at lectures of disloyal professors. Their modus operandi, typical for the Red Guards, was not very refined, but undoubtedly effective-lectures were interrupted, professors mocked and threatened, and any forms of civilized discussion precluded. Faced with the growing pressure, the Club of the Logophagoi ceased to exist in 1949. Less than a year later, one of its former organizers was arrested, soon after that, for the sake of the safety of other members, the club's book of registry was burnt. The short intellectual adventure was brutally ended.

After defending his $\mathrm{PhD}$ thesis and obtaining a Master's degree in sociology in 1951, Podgórecki had no chance of being hired by the university, but he continued to take part in various informal or clandestine seminars. In 1953 he began working as a

\footnotetext{
${ }^{3}$ In Poland an exceptionally interesting collection of essays and memoirs written by some surviving members of the Club, including Podgórecki, was published in 1996 (Rozmarynowicz 1996).
} 
low-key legal adviser in an enterprise near Katowice. One of the discussion groups whose informal meetings he attended was organized by Czesław Czapów in Warsaw at the beginning of the 1950s. ${ }^{4}$ It included some of the former Logophagoi. Christian personalism, personalistic socialism, and Marxism were talked over and critically examined. In one of his papers, Czapów described the phenomenon of "the new ruling class"; interestingly this was several years prior to the publication in 1957 of the internationally acclaimed The New Class: An Analysis of the Communist System by Milovan Djilas. The Czapów circle soon became the subject of surveillance by the communist political police, who had a secret agent operating within the group. The police surveillance and infiltration, which lasted from January 1951 to December 1953, concerned several dozen people. Eventually, a few were arrested, a dozen or so were detained and interrogated. The secret police regarded those seminars as a beginning of a political plot. Podgórecki was detained in October 1953 (Wicenty 2010a). He was probably kept under arrest for at least several days, brutally interrogated (beaten, sleep deprived), starved and intimidated (threatened with death and a long imprisonment). Some of the interrogated were encouraged to cooperate with the secret service. In the end, nobody was charged and the arrested were released, although some were eventually re-arrested. The release of the suspects was likely in the interest of the secret police, who could thus continue their surveillance operations in order to get a deeper insight into various networks and their connections. It became clear, however, that in the eyes of the Stalinist authorities no discussion groups concerned with Western sociology and humanities could be innocent.

\section{The beginning of the academic career}

Despite Stalinist repressions, the idea of "invisible universities" proved indomitable. Informal discussion circles were being formed around some Warsaw professors and attracted young intellectuals. Following Stalin's death and the beginning of a degree of political thaw in the USSR, some relaxation of totalitarian control also reached Poland. As Jakub Karpiński recalls, "[i]n late 1955 and early 1956, intelligentsia clubs were forming throughout the entire country. By the spring of 1956, there were approximately 130 such clubs" (Karpiński 1982: 41). They were run semi-officially. In the mid 1950s the Crooked Circle Club was formed in Warsaw. Considered to be an enclave of a relatively free exchange of ideas, it attracted many sociologists, economists, publicists, writers, party and non-party people. ${ }^{5}$ The atmosphere of debate, a degree of heresy (in relation to the Marxist-

\footnotetext{
${ }^{4}$ From that moment Czapów's and Podgórecki's paths of life converged. Czapów, along with Podgórecki, was a founding father of the Institute for Social Prevention and Resocialization at the University of Warsaw in the early 1970s. Later, after an imposed reorganization of the Institute in 1976, first Podgórecki, then Czapów were sacked. Czapów, who died prematurely in 1980, is another example of an original scholar, criminologist, and educator, whose intellectual potential was blocked and health ruined in communist Poland (Kaczyńska 2003).

5 Its formation was surrounded by controversy. Polish historians are engaged in a dispute as to what extent the Club was initiated and inspired by the security apparatus (see, for example, Friszke 2004; Jedlicki 1963). It was likely created to sound out the mood among the intelligentsia and identify potentially dangerous leaders and networks.
} 
Leninist ideology), and intensive social and intellectual life were the hallmarks of the Club and its thought-provoking weekly lectures.

It was in such enclaves of uncensored debate that Podgórecki sought intellectual inspiration and made some lasting friendships. ${ }^{6}$ It must have been at that time that he first met two distinguished pre-war scholars Tadeusz Kotarbiński and Maria Ossowska. ${ }^{7}$ In 1956 Kotarbiński offered him a junior appointment in the Centre of Logic of Warsaw University, and 2 years later, following the reinstatement of sociology as an academic discipline, Ossowska recommended him for a full-time academic position in her newly established Centre for History and Theory of Morality at the same university. Both Kotarbiński and Ossowska had some influence on Podgórecki's further intellectual (as well as personal) development. His conceptualization of sociotechnics as a practical social science is to some extend rooted in Kotarbiński's praxeology (Kojder 2000). Their regular meetings involved a broad range of topics and his mentor's outstanding mind and personality stirred Podgórecki's curiosity and provided intellectual stimulation. It could be argued that years later he tried to develop his relations with students and younger colleagues in a way somewhat reminiscent of the role Professor Kotarbiński, and Professor Lande before him, played in his own scholarly formation.

It was also Kotarbiński who encouraged him not to limit himself to exclusively academic writing and to publish his "Chinese stories". Kotarbiński loved paradoxes, so natural for cultures in the Far East. In the 1960s, enigmatic short stories, parables, and anecdotes signed by Si-tien, a fictitious Chinese sage, started to appear in some Polish journals. A first book edition was published in English in 1971 and was followed by over forty volumes, published mainly in England and Canada, but also in Poland, the USA and Germany. Podgórecki continued to write these adages of his Chinese alter-ego Si-tien till the end of his life. With time, Sitien gained a circle of loyal readers, including many intellectuals from Poland and countries all over the world. The well-known sociologists Robert K. Merton and Daniel Bell were among them, as documented in their many letters and commentaries on consecutive volumes. ${ }^{8}$ In the Foreword to the Polish edition of Social Theory and Social Structure, Merton observes that those stories' brilliant wisdom seems most striking when they sound least believable (Merton 1982: 9). With the political thaw came some opportunities to travel abroad. The Ford Foundation and Professor Paul F. Lazarsfeld of Columbia University facilitated research visits to the United States of a number of Polish sociologists. Podgórecki was among them. That was a memorable trip that opened entirely new horizons and opportunities. During a half-year Ford Foundation Scholarship at the Columbia University in 1959, he worked very hard doing library research, writing, attending seminars and cultural events, and exploring life in that amazing country. It was at Columbia University that he met Robert K. Merton for the first time. Hearing about his interest in sociology of law, Merton suggested that he become acquainted with

\footnotetext{
${ }^{6}$ For example, it was there that he met and made friends with Aleksander Matejko who later, in the 1970s, became like Podgórecki an involuntary emigrant and settled in Canada.

7 What is worth mentioning is that Ossowska was a former pre-war student of Kotarbiński.

8 Two volumes of Si-tien's stories were dedicated to Merton.
} 
William M. Evan, a researcher from Philadelphia (Sułek 2010: 339). Many years later, following Adam Podgórecki's death, Evan wrote: „I had the good fortune of meeting Adam [...] on his first visit to the United States. In the course of a wideranging conversation on the problems and challenges of the sociology of law we decided to submit a proposal to the Secretariat of the International Sociological Association to establish a Research Committee on the Sociology of the Law. Fortunately, our proposal was accepted. Together with colleagues from around the world we initiated a program of conferences and comparative research projects, which are continuing to this day" (quoted from Kwasniewski and Winczorek 2009: 297).

This first trip abroad proved momentous for Podgórecki, allowing him to take a lead in development of sociology of law internationally and connecting him with the world. Quickly, he gained international recognition as an original and influential researcher as well as a dynamic organizer. The contact with Merton resulted in a life-long friendship - they exchanged letters, books with dedications, sent one another manuscripts with requests for comments, and met in various places, all in the spirit of intellectual kinship and mutual respect. Yet, somewhat paradoxically, Podgórecki's growing scholarly recognition abroad did not help his position in Poland, as it raised both political suspicion and common envy. ${ }^{9}$

Still, he was allowed from time to time to take advantage of some of the numerous invitations he received from foreign universities, and even before his involuntary emigration in 1977 he gathered invaluable experience as a fellow or visiting professor at such prestigious institutions as Oxford University (All Souls College, 1971), Stanford University (The Center for Advanced Study of the Behavioral Sciences, 1972) or the Law School of Northwestern University. He also participated in and co-organized many international conferences.

Since foreign travel and contacts were viewed by the Security Services [Stużba Bezpieczeństwa, hereafter SB] as potentially subversive, it is not surprising that they kept a close eye on him. Thus, from as early as 1959 Podgórecki was "preventively" invigilated-his correspondence was routinely surreptitiously intercepted and read and other surveillance techniques were employed as needed. In the official SB terminology, he fell under the rubric of suspected "collaboration of a citizen of the People's Republic of Poland with the Western centres of sabotage". In 1963 he was summoned twice to the SB office. On the second occasion, a formal attempt was made to recruit him as a secret collaborator. Podgórecki refused categorically. SB never asked again, which did not mean they lost their interest in his activities. From that moment they acted covertly, using more indirect tools of harassment and surveillance. Such activities continued till the end of 1970s (Wicenty 2010a, b). Incidentally, the newly disclosed and ongoing examination of evidence concerning the SB operational work in the academic milieu throws new light on the communist secret police's role in shaping the

\footnotetext{
${ }^{9}$ It is worthy of note that even today in the circles of Polish sociology there exist two diametrically different images of Podgórecki as a person. The first, cultivated mainly by his former students, shows an honest, courageous and considerate individual. The other portrays him in clearly negative terms as someone perennially quarrelsome and controversial. It will be a biographer's task to explore and assess those divergent opinions (Wicenty 2013).
} 
academia. It acted as a meta-agency, using ramified and discreet social arrangements, in order to groom and promote selected scholars while undermining the careers and damaging the reputations of others.

\section{The creation and decline of the Institute for Social Prevention and Resocialization}

The early 1970s were relatively auspicious for Polish sociology. When Edward Gierek became the Polish United Workers' Party's First Secretary [Polska Zjednoczona Partia Robotnicza, hereafter PZPR], he announced a new policy of openness towards academia and fresh opportunities for researchers, including those who were not party members. Sociology started to benefit; new research centers came into being and significant funds came from the state budget. The price that social sciences would eventually pay was their complicity in legitimizing the communist policy of "the leap of modernization" (Wicenty 2009). Podgórecki in a way benefited from the new political climate; together with a group of colleagues (first of all with Czapów) he could finally put into practice his old idea to found a research institute implementing the ideas of sociotechnics. It was founded in 1972 as the Institute for Social Prevention and Resocialization (Instytut Profilaktyki Społecznej $i$ Resocjalizacji, hereafter IPSiR) at the University of Warsaw. IPSiR was originally intended to perform the following three functions: (1) to produce diagnosis and expert reports on social and organizational pathologies, (2) conduct research, and (3) provide expert education (PhD studies and a program of studies for future workers of the administration of justice and social welfare). The expert and research activities were to play the key role. Podgórecki became the head of the Institute's section on Sociology of Norms and Social Pathology. It was eventually comprised of seventeen, mostly young, academic staff, none of whom was a member of PZPR, which was a major departure from the accepted standards for social sciences. Within a short time IPSiR gained a solid reputation. A pioneering research on the real extent of poverty in the People's Republic of Poland was carried out. The forms and scale of various systemic pathologies were revealed. The institute's researchers produced a critical analysis of draft bills concerning social parasitism and mental health. To their astonishment, their efforts proved effective and the bills were withdrawn. This was a considerable achievement as they were patterned on Soviet laws designed to suppress any form of dissent or failure to conform. At that time, Podgórecki wrote several ground-breaking papers about organizational pathologies, tertiary social control, and dirty togetherness. ${ }^{10}$

Before long it became clear that the mission of exposing and addressing social pathologies was going to cause IPSiR serious problems. In 1973, a daring report was prepared under the lead of Adam Podgórecki outlining the key problems of Polish society and their systemic roots. Copies were sent to selected political decision-

10 "Dirty togetherness" refers to some informal circumstances within an organizations (interactions, more or less durable relations between members and interests bonding them together) which result in shifting crucial and mission-rooted goals. 
makers and research centers. Simultaneously, a research project was launched to explore cooperation between researchers and decision-makers in addressing social problems. Those initiatives were subjected to close scrutiny by the University authorities after the PZPR and the state administration started to send signals of disapproval. The research was halted, and some courses were eliminated from the curriculum. At the beginning of 1975, the IPSiR became a target of open attacks at meetings of the Warsaw University authorities. The official reasons given were as a rule completely different from the real ones. Allegations were made of improper pedagogical climate, poor quality of research and misuse of human resources. In reality, it was the expert activities of the institute that caused the greatest anxieties. A PZPR cell in the IPSiR set up a secret team whose task was to prepare organizational changes in the institute. The result of its work was a reform proposal that effectively banned any research and expert activities inconsistent with the communist government's point of view. For instance, research on social pathology was to be limited to ordinary crimes and individual pathologies.

Other repressive actions followed. The institute was eventually brutally "reorganized". The academic unit headed by Podgórecki was closed, several employees got the sack, and some others were moved to other departments of the University as punishment. Podgórecki found himself in the Philosophy Department. By 1977 various sanctions were imposed on almost twenty IPSiR faculty members. This entire process was described by Podgórecki in a diary he kept between October 1975 and October 1976-it was later published in English as A Story of a Polish Thinker. This book is an uncompromising description of the everyday life of a scholar fighting for intellectual independence under the communist regime. Nor does the author have mercy for himself. For instance, when pondering the issue of researchers' responsibility for potential misuses of their ideas, he writes: "I am starting to reflect on the possible harmfulness of the bastard (which sociotechnics may be) that I have let loose on the world" (Podgórecki 1986: 417). In another place, he coolly recaps the extent of the failure of one of his cherished creations: "The idea of a semi-autonomous Institute was destroyed. The previous program of the Institute was abolished and the students were forced to complete their studies at a new and very different institute; the research projects were dismantled or fundamentally revised" (Podgórecki 1986: 670).

The "reorganization" of the IPSiR and involuntary exile in the Philosophy Department were by no means the last acts of persecution directed against Podgórecki. At the approaching 5th Polish Sociological Convention, he was scheduled to present a paper on the holistic analysis of Polish society during the opening plenary session. Under the authorities' pressure, the organizers moved the paper to a different session. In the end, Podgórecki did not present the paper at all. Soon before the Convention, he was told by the University authorities that his passport could be unblocked conditional on his leaving the country before the Convention (Wicenty 2010b).

It was not an easy decision, but in the end he resolved to take advantage of the remaining several months of his year-long fellowship at the Netherlands Institute for Advanced Study in the Humanities and Social Sciences (NIAS). While there, it became soon apparent that he was seriously ill and needed major surgery. In 1978 
he joined the faculty of the Centre for Socio-Legal Studies at Oxford University (Wolfson College) and became actively involved in building bridges between sociology and law in Britain. With this goal in mind, he organized in October 1978 a conference on Sociological Approaches to Law, held at Corpus Christi College in Oxford. This conference was a starting point for a book under the same title, edited by him and Christopher Whelan, also of the Wolfson College Centre (Podgórecki and Whelan 1981).

His life changed again when he was unexpectedly offered a Professorship in Sociology and Anthropology at Carleton University in Canada, were he had taught as a visiting professor during the summer of 1974. He went to Ottawa in January 1979 and worked there for the rest of his life to be eventually granted a very rarely bestowed title of a Distinguished Research Professor. ${ }^{11}$ By the way-this Canadian destination turned to be also determinative of the future life of Maria Łoś, whom Podgórecki married in $1978 .{ }^{12}$ Adapting to the realities of Western academia was by no means easy; the expectation of constant self promotion resembling a role of salesman in relation to potential publishers and granting agencies was probably the hardest. As he soon realized, instrumental attitudes in science, so distant from his understanding of a scholar's mission and so repellent to him in communist Poland had their Western equivalents (Podgórecki 1997: 39-46).

\section{The reception of Podgórecki's work in the West}

How was he perceived by Western sociologists? What standing was he able to achieve? I have limited my analysis of the reception of his work to the following two dimensions: the published reviews of his books and journal references to his works. The domain of the research is the database of selected, well-known journals, JSTOR. The known shortcomings of this measure notwithstanding, the recognition of an author and the rank of the journals in which Podgórecki's surname appeared can indicate the standard position granted to him by his peers.

Let us start with the reviews of the books published in English (I have taken into account review articles as well); here they are in chronological order:

- Law and Society (Boston, London: Routledge \& Kegan Paul, published in 1974): four reviews (Connor 1976; Mungham 1975; Sissons 1976; Stinchcombe 1977; Sumner 1975);

\footnotetext{
11 After Podgórecki's death, the Dean of Arts and Social Sciences at Carleton University, Professor William Jones, wrote to his widow, Maria Łoś: “The position of Distinguished Research Professor is jealously guarded by the University and awarded only to scholars who are at the head of their field. Adam, in fact, was one of the true giants in the discipline" (letter dated August 24, 1998).

12 The story of Maria Łoś is parallel to Podgórecki's life in astonishingly many aspects and deserves broad elaboration itself. Her academic career started at Warsaw University, where she was involved in the process of constituting IPSiR and finally shared with Podgórecki the role of victim of its "reorganization". She also left communist Poland in late 1970's and got compulsory exile status. In Canada Maria Łoś as a recognized social researcher was a professor of criminology at the University of Ottawa for 26 years (1981-2007).
} 
- Practical Social Sciences (Boston, London: Routledge \& Kegan Paul, 1975): one review (Gomez Greber 1980);

- Multi-Dimensional Sociology co-authored with Maria Łoś (Boston, London: Routledge \& Kegan Paul, published in 1979): five reviews (Camic 1982; Fletcher 1981; Peterson 1981; Rehorick 1981; Ritzer 1981);

- Sociological Approaches to Law edited by Podgórecki and Christopher J. Whelan (London: Croom Helm, published in 1981): four reviews (Griffith 1982; Hagan 1983; Matejko 1983; Weaver 1983);

- A Story of a Polish Thinker (Köln: Verlag für Gesellschaftsarchitektur, published in 1986): one review (Gella 1989);

- Polish Society (Westport: Praeger, published in 1994): four reviews (Kennedy 1995; Krygier 1995; Misztal 1995; Szlek Miller 1997);

- Social Engineering edited by Podgórecki, Jon Alexander and Rob Shields (Ottawa: Carleton University Press, published in 1996): one review (Matejko 1997a);

- Higher Faculties. A Cross-National Study of University Culture (Westport: Praeger, published in 1997): one review (Matejko 1997b).

The number of the reviews is considerable. ${ }^{13}$ They were printed in prestigious magazines, such as The British Journal of Sociology, Social Forces, Contemporary Sociology, Law \& Society Review and Law \& Social Inquiry. Moreover, apart from a few clearly critical evaluations-one of them, by Collin Sumner, will be mentioned again later-most reviewers produced favorable or relatively favorable evaluations of Podgórecki's books. A few reviewers drew attention to poor translations of his works into English. Nevertheless, it must also be noted that some of his English language books have not been reviewed in English in any of the JSTOR journals. They were:

- Knowledge and Opinion about Law edited by Podgórecki, Wolfgang Kaupen, J. van Houtte, P. Vinke and Berl Kutchinsky (London: Martin Robertson, 1973);

- Legal Systems and Social Systems edited by Podgórecki, Christopher J. Whelan and Dinesh Khosla (London: Croom Helm, 1985);

- A Theory in the Sociology of Law (Milano: Giuffre Editore, 1991);

- Social Oppression (Westport: Greenwood Press, 1993); Totalitarian and PostTotalitarian Law edited by Podgórecki and Vittorio Olgiati (Dartmouth: Aldershot, 1996).

The list is not long, but time related. Apart from a few exceptions, it can be observed that the keen interest in Podgórecki's work lasted from the early 1970s to the early 1980s. A similar conclusion can be drawn based on citations of Podgórecki's works. Most of the 36 (JSTOR base) articles quoting and/or referring

\footnotetext{
13 As useful points of reference we may cite, on the one hand, one of the classics of world sociology Erving Goffman, and on the other Piotr Sztompka, currently one of the most reviewed Polish sociologists. According to JSTOR, Goffman's Forms of Talk (1981), one of his most frequently reviewed books had eleven reviews. In the case of Sztompka, his most reviewed books Society in Action: The Theory of Social Becoming (1991) and Robert K. Merton: An Intellectual Profile (1986) each received five reviews.
} 
to the Polish researcher's works were published in the 1980s (Fig. 1). Taking into consideration the fact that a certain time must pass between a publication of a book and its absorption by fellow academics, the reception of Podgórecki's work resembles a wave that rises in the 1970s and crests sometime in the 1980s.

The next question that needs to be asked concerns the specific works (thus ideas) of Podgórecki that are most often referred to. The results, presented in Fig. 2, show clearly that his ideas related to sociology of law have evoked by far the most interest. Moreover, the lack of reviews of Knowledge and Opinion about Law edited by Podgórecki et al. seems relatively irrelevant given that it is the work that is most often referred to.

The unequivocal identification of Podgórecki as a sociologist of law at the expense of his other interests is confirmed in two articles presenting Podgórecki's intellectual profile. It is characteristic that both were written in 1977, when the Polish sociologist attracted great interest. The first article, written by Zdzisława Walaszek, discusses major developments in Polish sociology (Walaszek 1977). While it mentions Podgórecki's work in sociology of deviance and sociotechnics, it presents him above all as a pioneer of empirical research in the sociology of law. The other article, written by Klaus A. Ziegert, places the Polish scholar squarely in the field of sociology of law, as attested by the very title of the piece-Adam Podgórecki's Sociology of Law: The Invisible Factors of the Functioning of Law Made Visible (Ziegert 1977). A similar, almost exclusive focus on the sociology of law may also be found in other articles devoted to Podgórecki's ideas and published in languages other than English (Treves 1963; Ziegert 1975). An exception is a Dutch paper entitled The Social Engineer that offers a comparison between Roscoe Pound and Podgórecki (Huyse and Vandekerckhove 1978).

A strong identification of a researcher with a specific (sub-)discipline has certain consequences. In the case of Adam Podgórecki, the fact that he was so strongly identified with the sociology of law, as its co-creator and active promoter, might have undermined the visibility of his other works not directly related to law. This may partly explain the relative paucity of references to his later books, such as Social Oppression (1993), Social Engineering (1996), and Higher Faculties (1997).

Based on some basic theses of the sociology of knowledge, it may be expected that creative endeavours are both influenced by and influence the life experience of the creator. While they are conduits for more or less influential ideas and their

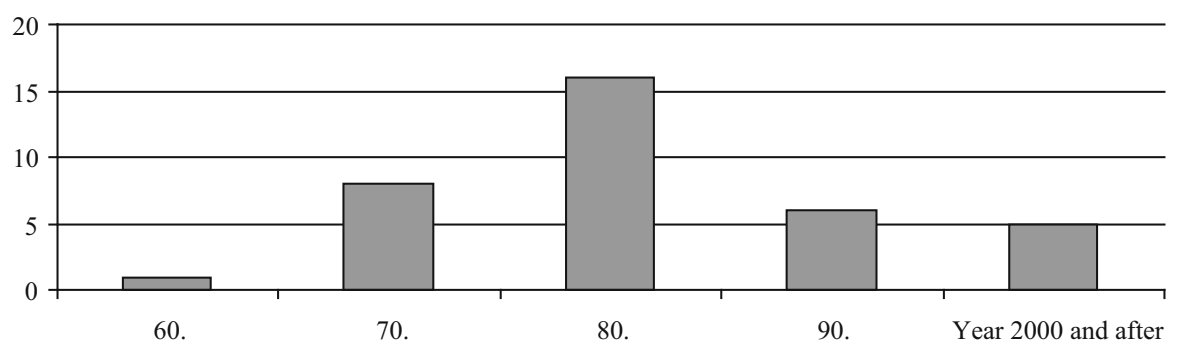

Fig. 1 The number of English-language articles quoting Adam Podgórecki's works in individual decades. Source: the JSTOR base 


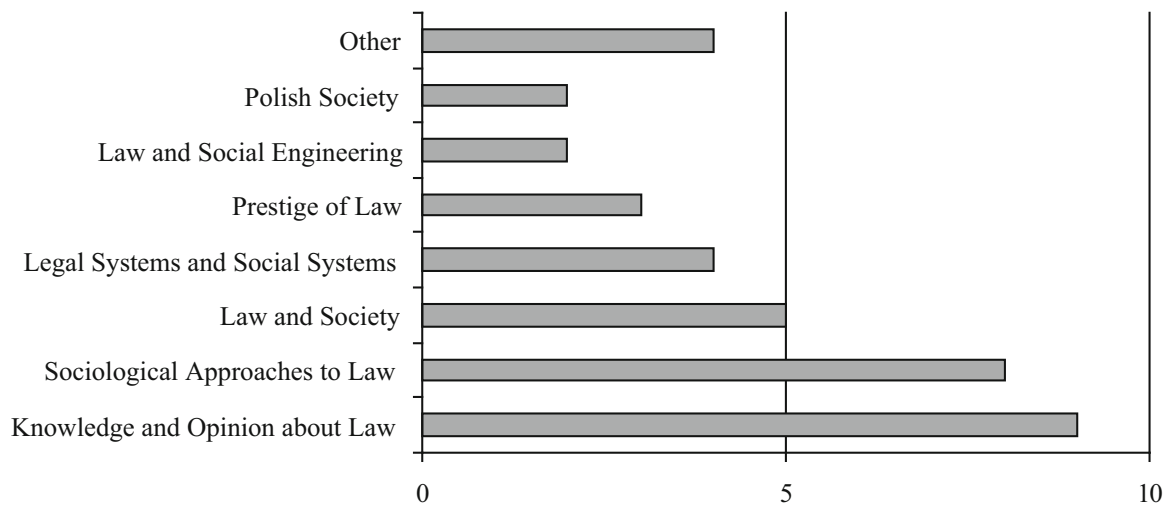

Fig. 2 The number of references to individual works of Adam Podgórecki in English-language articles. Source: the JSTOR base

dissemination, they also have considerable bearing on what academic circles their author becomes associated with. These circles are likely to become both the recipients of his or her ideas and providers of resources that can be utilized for further advancement. Podgórecki's A Story of a Polish Thinker may serve as an example of a direct translation of experience into an original work. But his books can also be viewed through their impact on his life and his standing in the academic community.

Despite a broad range of intellectual interests, it was Podgórecki's early fascination with the idea of sociology of law that channelled his academic contacts and career opportunities in a certain way. His active and passionate involvement in building up this new discipline and its important European-based vehicle, the Research Committee on Sociology of Law of the International Sociological Association, resulted in his playing a vital role in bringing into existence a distinct academic community, with its specific dynamics, patterns of communication and reproduction, hierarchies and changing intellectual fashions.

According to Podgórecki, the European focus of the early years of the Research Committee manifested itself in a great preoccupation with the totalitarian experience of twentieth century Europe. In particular, "Italian sociology of law was, to some degree, a reaction against the former fascist regime in Italy, while Polish sociology of law was generated as an internal academic protest against the reigning Marxist totalitarianism; the two schools have been closely linked by their antiauthoritarian political stance." (Podgórecki 1997: 124). When, however, the principled and idealistic motivations that had animated the early phase of the Committee's development were gradually overtaken by processes of professionalization and institutionalization of the sociology of law, Podgórecki started to voice his concern. While these processes were a sure sign of the success of this new discipline - which was rapidly gaining acceptance and maturity-they also shifted its focus from a free and unencumbered intellectual co-operation to a preoccupation with academic infrastructural arrangements, turf-staking, and competition for resources. He became alarmed that the Committee was being turned into a 
convenient springboard and "a vehicle for advancement of one's personal career" (Podgórecki 1997: 126).

It was thus a typical process of the institutionalisation of an idea-based movement that led to Podgórecki's eventual disenchantment with what he saw as an abandonment of the initial commitment to essential, universal values and a selfless scholarly quest. Yet his exasperation with the process of sociology of law's administrative "normalization", with its concomitant array of material arrangements and vested interests, may gain an additional dimension when viewed in the context of his unique biography. Arguably, his earlier experience of underground education networks in Nazi-occupied Poland and "invisible colleges" or "flying universities" under communism might have instilled in him a notion that true knowledge was born from sacrifice and suffering and tested through personal courage and integrity.

This expectation was likely reinforced by his high regard for the ethos of traditional Polish intelligentsia. Fully formed in the nineteenth century, when Poland was partitioned among its neighbours, this unique social stratum consisted of educated people united by common values and a sense of mission understood as selfless service to their country (and other oppressed countries if needed) in the name of freedom, justice, and truth. Social cohesiveness of this stratum was enhanced by the criteria of trustworthiness as well as highly ritualized "good manners"- a combination that resulted in a gracious and deeply rewarding social milieu. In Podgórecki's own words: "Material possessions and power have never been natural rewards for the intelligentsia. Power is at the mercy of whimsy, and material assets can vanish overnight-but the pleasures of friendship, loyal camaraderie, and mutual entertainment are all relatively stable in comparison. In the process of its generation, the intelligentsia was able to amass «goods» of a more vital and lasting nature" (Los and Podgórecki 1979: 311).

What he was looking for in the academia was a sincere, courageous, and noble commitment to the pursuit of knowledge and that peculiar loyalty and steadfastness that can emerge in a dedicated group of colleagues who work together on a project that transcends their own selfish interests. He experienced it in Poland, first in his youth and later as a mentor to a group of students and younger colleagues under the oppressive communist rule. Perhaps he was also finding it in the initial efforts to build the foundations for the development of international (although mostly European) sociology of law.

His growing concern with the direction the sociology of law was taking is clear in the central theme of a workshop he organized in 1990. Richard D. Schwartz cites this event in his review of a book by William M. Evan: "In the summer of 1990, Adam Podgórecki convened an international group of twenty sociologists of law to address the question, "Why is theory in sociology of law in such a miserable state?»" (Schwartz 1991: 426). This clearly suggests a discipline that has lost its bearing but may also be read as Podgórecki's attempt to inspire his fellow sociologists of law to try to reach higher and be more audacious.

The sociology of law seemed to become a victim of its own success. Its rapid development had to accommodate several parallel streams rooted in distinct traditions. The main among them were European sociology of law, the law and 
society movement in the United States ${ }^{14}$ and British (critical) socio-legal studies. The speed of institutionalization of these different strands of social science's interaction with the law might have prevented the formation of sound criteria and mechanisms that would allow distinguishing genuine scholarly works from the products of prevailing intellectual fashions, self-promotion or specious sophistry. Yet some of the problems described by Podgórecki were of a more general nature and concerned the social sciences in general. He was troubled by the prevalence of instrumental attitudes among sociologists which were turning the traditional role of a scholar into a "gainful profession" that offered opportunities for "scientific tourism" and absolved one from any responsibility or accountability (Podgórecki 1997: 123-128).

From the point of view of relatively standard theses of the sociology of knowledge, we can talk not only of the influence of life experience on a creation (the example of A Story of a Polish Thinker can be its clearest example), but also about the reverse relation. Creations change the environmental location or/and life situation of their creators. ${ }^{15}$ Creations not only constitute a carrier of more or less influential ("infectious") ideas, they also indicate a social circle that a creator belongs to, where her/his ideas circulate and whose intellectual resources she/he exploits. Generally speaking, such a circle defines for good or for ill a researcher's standing in the whole sociological circle. If Podgórecki fell from the crest of a rising wave gradually into relative oblivion from 1980s (as the JSTOR base indicates), the reason for this may have been the shape of the sociology of law, its vitality and popularity. Such a hypothesis would require an independent and detailed examination.

Another possible factor complicating the perception of Podgórecki in the West relates to the fact that he was not a Marxist. In order to avoid any misunderstandings, we need to indicate that being a Marxist meant something different for a Western sociologist and a sociologist from communist Poland. For the former, Marxism meant one of many possible intellectual traditions. For the latter, it meant a shameful choice, not intellectual but purely opportunistic in nature. It entailed significant privileges but also certain duties, among which the readiness to legitimate the communist government was key. Marxism was a hated ideology and the refusal to embrace it was a sign of courage and integrity. But these differences have eluded many Western researchers. For example, Naomi Galtz and Michael D. Kennedy are puzzled why Polish Marxist sociologists abandoned the Marxist perspective immediately after the transformation in 1989. They note: "These intellectuals have no wish to engage Marxism, seeing the affinity with the tradition clearly as something to move beyond rather than to debate, much less to embrace" (Galtz and Kennedy 1996: 449). But they offer no explanation.

The irony was that while many sociologists in communist countries paid lip service to Marxism in exchange for security and promotions, from the late 1960s

\footnotetext{
${ }^{14}$ Law and Society Association was established in the USA in 1964, 2 years after the creation of the Research Committee on Sociology of Law (ISA). It grew rapidly and now counts thousands of members.

15 For an interesting example of such an approach to the biographical analysis—-see McLaughlin (1998).
} 
onwards it was being enthusiastically embraced by their Western counterparts. ${ }^{16} \mathrm{~A}$ sudden elevation of the Marxist paradigm to the status of one of the dominant orientations in both general sociology and sociology of law had clear repercussions for Adam Podgórecki. Mannheim's sociology of knowledge points to a significant role of competition and contest in the dynamics of the social sciences. The goal is above all to win universal acceptance for a particular interpretation of reality (Mannheim 2003/1929: 132). Opponents are criticized from the position of moral superiority, prevalence, and/or the obviousness of one's version of the world. Clearly, in the eyes of some reviewers of Podgórecki's books, his interpretations of Polish reality were flawed because of his failure to use the Marxist perspective. One of the reviewers of Multi-Dimensional Sociology is disappointed that the authors (Podgórecki and Łoś) "do not attempt to revitalize [the Marxist tradition] or to draw from it for a systematic critique of Eastern socialism" (Peterson 1981: 302). In this case, the lack of any references to Marxist thought did not provoke fundamental criticism but only a mild reprimand. On other occasions, however, Podgórecki's books were read unequivocally critically from Marxist positions. For instance, in Sumner's review of Law and Society we read: "Opponents of Marxism will be pleased to find a total absence of Marxist/socialist/revolutionary ideas in this text and the total presence of a development of the logic of capitalist, structuralfunctionalist sociology" (Sumner 1975: 247). According to this (not very substantial) criticism, non-Marxist sociology becomes automatically a science of capitalists and a "functional fantasy" within a "Rent-a-Science" market. Ziegert, who was already mentioned here, sums up Sumner's review thus: "Clearly Sumner is disappointed by the absence of Marxist components in Podgórecki's sociology of law, and cannot conceal his contempt for a Polish sociologist who analyzes a socialist society by combining the concepts of Petrażycki with those of empirical sociology (necessarily of western provenience)" (Ziegert 1977: 152). If then Marxism played such an important role in gauging the merits of scholarly work, it would be in the interest of the "newcomers from the East" to appear to be steeped in Marxist thought and use it as a catapulting mechanism in Western academic circles. From this point of view, it is easier to understand the international careers of Leszek Kołakowski (first a passionate Marxist and later critic of Marxism in his threevolume Main Currents of Marxism) ${ }^{17}$ and Zygmunt Bauman (who, it seems, never gave up on Marxism). Podgórecki was not prepared, however, to play these games.

\footnotetext{
16 The publication and reception of The Coming Crisis of Western Sociology by Alvin W. Gouldner from 1970 can be the milestone of the process of the increasing influence of Marxism on Western sociology.

17 Those elements of Kołakowski's involvement were criticised at some point by David Joravsky in a review article of Main Currents of Marxism (Joravsky 1981). Podgórecki talked about Kołakowski's scientific volte-face critically many times; presenting him as an example of a semi-instrumental scholar, he wrote "Kolakowski's main treatise, Main Currents of Marxism (1978) is a repetition of his earlier lectures in Warsaw during the Stalinist period. In the Western edition, instead of placing a «yes» before each sentence, he blithely substitutes a «no»" (Podgórecki 1997: 111).
} 


\section{Between two worlds}

Another element influencing the reception of Podgórecki's work in the West is his specific status as a sociologist suspended between two distinct social realities. Ziegert described Podgórecki in a somewhat romantic fashion as a wanderer between two very different worlds of the East and the West. "Podgórecki's effort to adapt his work for an English-reading audience is symptomatic of his unique position. [...] This position must affect the nature of his scientific production. A person who bridges two worlds seldom satisfies the expectations of those whose loyalties belong exclusively to one or the other; yet he can serve to cross-fertilize the established ways of thinking in both worlds in a highly stimulating manner" (Ziegert 1977: 151-152). This, of course, was not always easy.

Podgórecki was keenly aware of dramatic differences between these two social realities and struggled against the superficiality of assumptions and mutual perceptions of sociologists on both sides of the divide. Trying to convey to his Western colleagues and readers some of the complex lessons and experience gained during his earlier years in Poland he was searching for a sociological language that would negotiate the barriers to understanding the other society's experience. Not surprisingly, it was not the familiar language of the latest sociological fashion.

In such books as Polish Society and Higher Faculties he tackles some issues related to the lingering effects of the Polish sociology's lack of intellectual autonomy under communism. In the case of A Story of a Polish Thinker, a daily record of personal experience, he offers in effect an uncompromising exposé of real mechanisms that governed scientific life under communism. These books may make for uncomfortable reading for those Western scholars who made some effort to become familiar with Polish sociology of the communist period and took it a face value. In his review of Polish Society, Misztal remarks: "For many American scholars who have had contact with Polish sociologists, this work will hardly be comfortable, since it offers an erudite «who's who» in discussing the crippled intellectual potential of sociology in Poland" (Misztal 1995: 1638).

While Podgórecki's gritty analyses may seem too critical for many Western readers, the nuances of his portrayal and theoretical analysis of the mechanisms of communist government legitimization by sociologists may simply escape them. ${ }^{18}$ Michael Kennedy's analysis suggests this indirectly, when he writes that Poland in communist times was perceived by American sociologists as a friendly country compared with other communist countries in Central Eastern Europe (Kennedy 2004). In Poland, they could conduct research relatively comfortably, count on an open and helpful attitude in academic and research centers, and meet interesting interlocutors. Even party sociologists did not make the impression of dull orthodox Marxists. For all these people, Podgórecki's criticism of Polish sociology and humanities-criticism, let me add, often quite specific and personal-must have brought a form of cognitive dissonance by generating tension between the knowledge acquired and one's own images and experiences. Such a discrepancy

\footnotetext{
18 In this context Gella in the review of A Story of a Polish Thinker wrote about "naïve views of Westerners" (Gella 1989: 311).
} 
would be diminished by shifting attention from the merit of the case to a personalized ethical and emotional sphere. It is much easier to query whether the critical remarks in Podgórecki's works might be the echoes of a Polish researcher's frustrations. Why did he present his colleagues in such dark colors? The criteria of scientific analysis disappear; the questions about Podgórecki's personal motivations emerge in their place. ${ }^{19}$ And instead of the cross-fertilization envisaged by Ziegert he might have made enemies in both worlds.

Those prejudicial interpretations notwithstanding, the autobiographical elements and influences in the Polish sociologist's work are quite fascinating. Yet they have not been generally known. A Story of a Polish Thinker gave a unique insight into a dramatic moment in the Polish scholar's life, and it could be a good point of reference for the evaluation of all the other critical elements in his sociology. Unfortunately, it was published in Cologne, outside the American publishing market. Its range of influence was more than limited, and a single enthusiastic review did not improve the situation, especially as it was published in a rather specialized magazine, and not in any of the leading sociology journals.

The final element contributing to the falling wave of interest in Podgórecki was his academic affiliation in exile. Let me remind you that from 1979 till his death in 1998 he worked at Carleton University. It was regarded as a good university with one of the best Sociology Departments in Canada. Yet, as Diana Crane's research indicates, "[s]cientific recognition [is] related to the prestige of the scientist's current academic affiliation" (Crane 1965: 713). This of course creates some sort of a vicious circle, using a specific halo effect. Carleton does not count among the world's best universities. Despite his vibrant participation in international academic life till his death, ${ }^{20}$ Podgórecki did not have the advantage of a prestigious academic affiliation. Still, it might have given him the quiet distance from the noise of academic vanity markets and his own unique vantage point.

\section{Is a revival of interest in Adam Podgórecki's ideas possible?}

I believe that Podgórecki's conceptual potential has been recognized and utilized in social sciences only to a limited extent. Yet it does not seem very likely that this will suddenly change and that a renewed interest in his work will inspire a re-reading of his major contributions to sociology of law and sociotechnics. A possible obstacle is, paradoxically, his status of a classic in these areas, perhaps not universally accepted but a classic nonetheless. And a classic_as Podgórecki himself once stated-is "somebody who is quoted, but not read" (quoted from Kojder 2009: 38).

There are, however, good prospects for a renewed interest in his specific ideas that are often sketched and not fully developed or empirically tested but striking in their originality and heuristic potential. They can be found in his writings on

\footnotetext{
19 Even Kennedy, who knows the Polish realities so well and who highly valued Podgórecki, finishes his review of Polish Society with a remark about the Polish sociologist's frustrations and his emotional involvement in the described phenomena (Kennedy 1995: 223).

20 Two weeks before his death, he actively participated in Sociology of Law and Sociotechnics sessions and board meetings at the World Sociological Congress in Montreal.
} 
organizational misconduct, dirty togetherness, tertiary social control and so forth. They might have been considered by some readers as sidelines, not germane to Podgórecki's main body of work, but if the history of science does teach anything, it will be the reality that such seeming side-roads sometimes turn with years into "royal roads." The inspirational value of those ideas has already been proven. A number of Polish researchers has re-visited them in recent years and applied them in their explorations of post-1989 reality (see, for instance, Zybertowicz 2009). ${ }^{21}$ Janine R. Wedel, a well-established American researcher of East/Central Europe utilizes these concepts regularly in her publications (Wedel 1998, 2001, 2009) as do many other authors (Czarnota and Krygier 2006; Hignett 2010). Despite their particular relevance to post-totalitarian societies, these conceptions have much more universal import and could prove extremely fertile in other contemporary contexts.

The depth of Adam Podgórecki's ideas is intimately related to his biography. His credibility as a researcher is closely (and painfully) connected with his integrity as an individual who was schooled in life and tested by the mechanisms of social oppression.

Open Access This article is distributed under the terms of the Creative Commons Attribution 4.0 International License (http://creativecommons.org/licenses/by/4.0/), which permits unrestricted use, distribution, and reproduction in any medium, provided you give appropriate credit to the original author(s) and the source, provide a link to the Creative Commons license, and indicate if changes were made.

\section{References}

Camic, C. (1982). Review: Multi-dimensional sociology by Maria Łoś and Adam Podgórecki. Contemporary Sociology, 11(4), 462-463.

Connor, W. D. (1976). Review: Law and society by Adam Podgórecki. Social Forces, 54(4), 955-956.

Crane, D. (1965). Major and minor universities: A study of productivity and recognition. American Sociological Review, 30(5), 699-714.

Czarnota, A., \& Krygier, M. (2006). After postcommunism: The next phase. Annual Review of Law and Social Science, 2, 299-340.

Fletcher, C. (1981). Review: Multi-dimensional sociology by Maria Łoś and Adam Podgórecki. The British Journal of Sociology, 32(3), 435-436.

Friszke, A. (2004). Początki Klubu Krzywego Koła. Zeszyty Historyczne, 149, 44-86.

Galtz, N., \& Kennedy, M. D. (1996). From marxism to postcommunism: Socialist desires and East European rejections. Annual Review of Sociology, 22, 437-458.

Gella, A. (1989). A struggle for an intellectually independent institute: The case in Poland. Studies in Soviet Thought, 37(4), 307-315.

Gomez Greber, F. (1980). Review: Practical social science by Adam Podgórecki. Contemporary Sociology, 9(2), 299-300.

Griffith, J. A. G. (1982). Review: Sociological approaches to law edited by Adam Podgórecki and Christopher J. Whelan. Journal of Public Policy, 2(1), 79-81.

Hagan, J. (1983). From the shadow of the law. Contemporary Sociology, 12(1), 35-37.

Hignett, K. (2010). The changing face of organized crime in post-communist central and Eastern Europe. Debatte: Journal of Contemporary Central and Eastern Europe, 18(1), 71-88.

Huyse, L., \& Vandekerckhove, L. (1978). De sociale ingenieur. Tijdschrift voor Sociale Wetenschappen, 23(3), 219-236.

Jedlicki, W. (1963). Klub Krzywego Koła. Paris: Instytut Literacki.

\footnotetext{
${ }^{21}$ From among his many books published in English, only two were translated into Polish: Polish Society (1994) was published in Poland in 1995 and A Sociological Theory of Law (1991) in 1998.
} 
Joravsky, D. (1981). Kolakowski's long goodbye. Theory and Society, 10(2), 293-305.

Kaczyńska, W. (Ed.). (2003). Czestaw Czapów 1925-1980: świadectwa trzech pokoleń. Warszawa: Uniwersytet Warszawski.

Karpiński, J. (1982). Countdown. The Polish upheavals of 1956, 1968, 1970, 1976, 1980.... New York: Karz-Cohl.

Kennedy, M. D. (1995). Review: Polish society by Adam Podgórecki. Contemporary Sociology, 24(2), 222-223.

Kennedy, M. D. (2004). Poland in the American sociological imagination. Polish Sociological Review, 4, 361-383.

Kojder, A. (1999). Adam Podgórecki's Vita Activa. Polish Sociological Review, 2(126), 323-330.

Kojder, A. (2000). Droga Adama Podgóreckiego do socjotechniki. In J. Kubin \& J. Kwaśniewski (Eds.), Socjotechnika. Kontrowersje, rozwój, perspektywy (pp. 19-28). Warszawa: Uniwersytet Warszawski.

Kojder, A. (2009). Anegdoty. Limeryki. Epifanie. O socjologii i socjologach. Warszawa: Oficyna Naukowa.

Krygier, M. (1995). The constitution of the heart. Law \& Social Inquiry, 20(4), 1033-1066.

Kwaśniewski, J., \& Winczorek, J. (Eds.). (2009). Idee naukowe Adama Podgóreckiego. Warszawa: Uniwersytet Warszawski.

Łoś, M., \& Podgórecki, A. (1979). Multi-dimensional sociology. London: Routledge.

Mannheim, K. (2003/1929). Competition as a cultural phenomena. In G. Delanty, \& P. Strydom (Eds.), Philosophies of social science. The classic and contemporary readings (pp. 128-133). Maidenhead, PA: Open University Press.

Matejko, A. (1983). Review: Sociological approaches to law edited by Adam Podgórecki and Christopher J. Whelan. The Canadian Journal of Sociology, 8(1), 107-111.

Matejko, A. (1997a). Review: Social engineering edited by Adam Podgórecki, Jon Alexander and Rob Shields. Canadian Slavonic Papers, 39(1/2), 281-285.

Matejko, A. (1997b). Review: Higher faculties. A cross-national study of University Culture by Podgórecki. Canadian Slavonic Papers, 39(3/4), 517-518.

McLaughlin, N. (1998). How to become a forgotten intellectual: Intellectual movements and the rise and fall of Erich Fromm. Sociological Forum, 13(2), 215-246.

Merton, R. K. (1982). Teoria socjologiczna i struktura społeczna. Warszawa: Państwowe Wydawnictwo Naukowe.

Misztal, B. (1995). Review: Polish society by Adam Podgórecki. Social Forces, 73(4), 1637-1638.

Mungham, G. (1975). Review: Law and society by Adam Podgórecki. The British Journal of Sociology, 26(4), 509.

Peterson, R. T. (1981). Review: Multi-dimensional sociology by Maria Łoś and Adam Podgórecki. Philosophy and Phenomenological Research, 42(2), 301-303.

Podgórecki, A. (1962). Socjologia prawa. Warszawa: Wiedza Powszechna.

Podgórecki, A. (1966). Zasady socjotechniki. Warszawa: Wiedza Powszechna.

Podgórecki, A. (1980/1981). Unrecognized father of sociology of law: Leon Petrażycki. Reflections based on Jan Górecki's Sociology and Jurispridence of Leon Petrażycki, Law \& Society Review, 20(1), 183-202.

Podgórecki, A. (1986). A story of a Polish Thinker. Köln: Verlag für Gesellschaftsarchitektur.

Podgórecki, A. (1997). Higher faculties. A cross-national study of university culture. Westport: Praeger.

Podgórecki, A., \& Whelan, C. (Eds.). (1981). Sociological approaches to law. London: Croom Helm.

Rehorick, D. A. (1981). Review: Multi-dimensional sociology by Maria Łoś and Adam Podgórecki. The Canadian Journal of Sociology, 6(2), 195-197.

Ritzer, G. (1981). Review: Multi-dimensional sociology by Maria Łoś and Adam Podgórecki. Social Forces, 60(2), 610-612.

Rozmarynowicz, A. (Ed.). (1996). Klub Logofagów. Wspomnienia. Kraków: Znak.

Schwartz, R. D. (1991). Review: Social structure and law: Theoretical and empirical perspectives by William M. Evan. Contemporary Sociology, 20(3), 426-427.

Sissons, P. L. (1976). Review: Law and society by Adam Podgórecki. Contemporary Sociology, 5(4), 434-435.

Stinchcombe, A. L. (1977). Review: Law and society by Adam Podgórecki. Law \& Society Review, 12(1), $127-131$. 
Sułek, A. (2010). "To America!". Polish sociologists in the United States after 1956 and the Development of Empirical Sociology in Poland. East European Politics and Societies, 24(3), $327-352$.

Sumner, C. (1975). Review: Law and society by Adam Podgórecki. British Journal of Law and Society, 2(2), 246-250.

Szlek Miller, S. (1997). Contending views on Poland in transition. Canadian Slavonic Papers, 39(1/2), 249-254.

Treves, R. (1963). Sociologia del diritto e politica legislative. A proposito di alcuni scritti di A. Podgórecki. Rivista Internazionale di filosofia del Diritto, 40(6), 743-747.

Walaszek, Z. (1977). Recent developments in Polish sociology. Annual Review of Sociology, 3, 331-362.

Weaver, M. (1983). Review: Sociological approaches to law edited by Adam Podgórecki and Christopher J. Whelan. The Modern Law Review, 46(1), 116-118.

Wedel, J. R. (1998). Informal relations and institutional change: How Eastern European cliques and states mutually respond. The Anthropology of East Europe Review, 16(1), 4-13.

Wedel, J. R. (2001). Corruption and organized crime in post-communist states: New ways of manifesting old patterns. Trends in Organized Crime, 7(1), 3-61.

Wedel, J. R. (2009). Shadow Elite: How the world's new power brokers undermine democracy, government, and the free market. New York: Basic Books.

Wicenty, D. (2009). Zjazd zapomniany - zjazd obserwowany. O Piątym Ogólnopolskim Zjeździe Socjologicznym w Krakowie (22-25 stycznia 1977 r.). Przeglad Socjologiczny, 58(2), 105-127.

Wicenty, D. (2010a). Trzy dekady wobec SB: nieznany wymiar biografii Adama Podgóreckiego. Profilaktyka Społeczna i Resocjalizacja, 15, 199-254.

Wicenty, D. (2010b). Socjologia nieposłuszna w PRL? O funkcjonowaniu Zakładu Socjologii Norm i Patologii Społecznej w Instytucie Profilaktyki Społecznej i Resocjalizacji w latach 1972-1976. In D. Wicenty, \& P. Łuczeczko (Eds.), Jedna nauka - wiele historii. Dzieje subdyscyplin socjologicznych w Polsce (pp. 39-50). Gdańsk: Uniwersytet Gdański.

Wicenty, D. (2013). Wokół projektu biografii Adama Podgóreckiego: wyzwania koncepcyjne, metodologiczne i społeczne. Przeglad Socjologii Jakościowej, 9(4), 82-102.

Ziegert, K. A. (1975). Zur Effectivität der Rechtsoziologie und die Rekonstruktion der Gesellschaft durch Recht. Stuttgart: Enke.

Ziegert, K. A. (1977). Adam Podgórecki's sociology of law: The invisible factors of the functioning of law made visible. Law \& Society Review, 12(1), 151-180.

Zybertowicz, A. (2009). Kontrola społeczna trzeciego stopnia. In J. Kwaśniewski \& J. Winczorek (Eds.), Idee naukowe Adama Podgóreckiego (pp. 152-178). Warszawa: Uniwersytet Warszawski. 